\title{
Rethinking the 5 R's in Open Educational Resources: A Reuse Perspective
}

\author{
Silvia Scheunemann ${ }^{1}$, Anarosa Brandão ${ }^{2}$, Daniela Brauner ${ }^{3}$ \\ ${ }^{1}$ Departamento de Ciência da Computação \\ Instituto de Matemática e Estatística \\ Universidade de São Paulo (USP) - São Paulo - SP- Brazil \\ ${ }^{2}$ Departamento de Engenharia de Computação e Sistemas Digitais \\ Escola Politécnica \\ Universidade de São Paulo (USP)- São Paulo - SP- Brazil \\ ${ }^{3}$ Escola de Administração \\ Universidade Federal do Rio Grande do Sul (UFRGS) - Blumenau, SC - Brazil \\ silviass@ime.usp.br, anarosa.brandao@usp.br, daniela.brauner@ufrgs.br
}

Abstract. Open Educational Resources (OER) are digital learning resources available under public domain or open licenses that empower users with the 5Rs of freedom: reusing, reviewing, remixing, redistributing or retaining them for particular purposes. This paper states how reuse is related with the other Rs with the goal of paving the way to define traceability criteria for OER automatic quality evaluation.

\section{Introduction}

Open Educational Resources (OER) are teaching-learning resources, organized under any media, which are in public domain or have an open license. Open licenses provide different degrees of freedom to access, use, adapt and redistribute OER (UNESCO, 2012; Creative Commons, 2018). Standardized by Creative Commons (CC), they are the main feature of the OER, and are represented by six license subtypes: (i) Attribution (CC BY); (ii) Attribution ShareAlike (CC BY-SA); (iii) Attribution NoDerivs (CC BY-ND); (iv) Attribution Non-Commercial (CC BY-NC); (v) Attribution Non-Commercial Share-Alike (CC BY-NC-SA); (vi) Attribution Non-Commercial NoDerivs (CC BY-NC-ND) (Creative Commons, 2018).

Independent of the type of $\mathrm{CC}$ license, there are rights associated with OER. Initially, the OER community use to relate the rights of licenses to $4 \mathrm{R}^{\prime}$ 's (reuse, remix, review and redistribute) (Wiley, 2009; Butcher, 2015; UNESCO, 2012; Santos, 2014; Creative Commons, 2018). More recently, the fifth R (retain) was included by Wiley (2014), who defines it as "the right to make, own, and control copies of the content". It is the first mention to the author's ownership concerning the OER content. It is our claim that the 5Rs are essentially two (reuse and retain), and reuse can serve as baseline for defining quality criteria for OER while relating it and the other R's. 
VII Congresso Brasileiro de Informática na Educação (CBIE 2018)

Anais do XXIX Simpósio Brasileiro de Informática na Educação (SBIE 2018)

\section{OER and associated licenses}

Concerning open licenses, the Creative Commons initiative makes them available to guarantee the OER author's rights while allowing the OER sharing or editing.

The CC BY (attribution) license allows wide reuse, remix, review, and redistribution of OER and its derivatives. The CC BY-SA (attribution and share-alike) license allows wide reuse, remix, and review, but constrains OER derivatives redistribution to the same kind of license. The CC BY-ND license limits reuse to use "as is", no remix and no review are allowed, but wide redistribution of the original OER is granted if the credit for its authorship is provided. The CC BY-NC license allows wide reuse, remix and review but constrains OER derivatives redistribution to be noncommercial without establishing the type of license for the redistributed OER. Moreover, the CC BY-NC-SA license allows the same of BY-NC but obliges redistribution of OER derivatives with the same license. Finally, the CC BY-NC-ND license only allows the OER to be downloaded and shared, without changes and commercial use, being the most restrictive (Creative Commons, 2018). Nevertheless, none of the licenses explicitly mentions the OER content ownership in their definitions, not welcoming the fifth $\mathrm{R}$.

All CC licenses have a description in CC Rights Expression Language (CC REL) (Creative Commons, 2018) - a computer readable format. Therefore, automatic traceability of OER source could be conducted to evaluate its quality only by filtering license metadata information.

\section{Reuse Overview and the $5 R$ 's}

According to the Oxford Dictionary, reuse is use again, or use repeatedly. In Computer Science, the term reuse is adopted since the late 1960s (Krueger, 1992). Sommerville (2011), states that software reuse is the use of existing software or knowledge to build new software. After analysing the open licenses, we realize that the same occurs with OER: all of them allow the reuse of existing OER but the way this reuse is allowed is type-of-license, or its degree of openness dependent (Silveira, 2014), among others. We relate reuse to the other R's as a step towards defining criteria for automatic OER quality evaluation (according to figure 1).

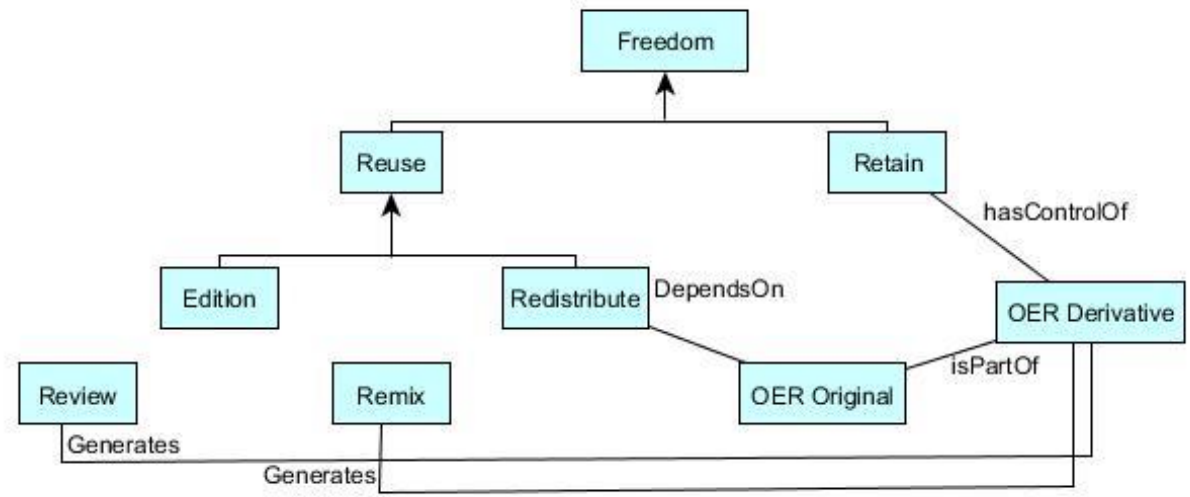

Figure 1: Taxonomy for OER Reuse 
VII Congresso Brasileiro de Informática na Educação (CBIE 2018)

Anais do XXIX Simpósio Brasileiro de Informática na Educação (SBIE 2018)

We state that the right granted for the licenses is, essentially, reuse. Nevertheless, reuse could happen by editing or redistributing the OER. Editing could be obtained by remixing or reviewing. After editing an OER, a derivative OER is generated from one or more original OER. As the fifth $\mathrm{R}$ is not explicitly in the licenses, retain is not categorized as reuse.

\section{Conclusion and future work}

This work presented a semantic analysis of the $5 \mathrm{Rs}$ based on reuse. We stated that $4 \mathrm{Rs}$ that characterize the rights of open licenses are, essentially, reuse. The freedoms assigned to OERs by their associated licenses are the basis for defining them. Quality in OER is an issue due to its very nature: the more freedom the OER license presents, the more difficult is to evaluate its associated quality. If we could assign any information regarding the OER quality, it is our claim that it could be reused in large scale and, therefore, achieves its main goal. The 5R's analysis provided a technical understanding about OER freedoms. Having such understanding will guide a mapping to technical and pedagogical criteria, which are common use to all learning resources. In this way, the use of computational techniques and quality metrics can be adopted to construct a model to evaluate quality in OER.

A step towards the model building is consider the fact that $\mathrm{CC}$ open licenses are described in CC-REL. Thus, some information regarding authorship, type of license, and redistribution are granted for free for its simple adoption. This would allow traceability of OER provenance and guide the definition of quality criteria to automatic quality evaluation of OER by simply analysing meta-information available in the license. Nevertheless, a combination of meta-information sourced from learning resources repositories and the licenses could be explored with the same aim. Other possibility is extending CC-REL to include more information that may, for instance, welcome the fifth $\mathrm{R}$, which means content ownership and version control.

\section{References}

Braga, Juliana Cristina et al. Desafios para o desenvolvimento de objetos de aprendizagem reutilizáveis e de qualidade. In: DESAFIE! 2012, Curitiba. Anais... Curitiba/PR:CEIE/SBC, 2012. p. 90-99.

Braga, J., Costa, A.K.N.C., Melo, A.M., Cechinel, C., Menezes, L., Pafunda, R.A., Frango, I. "Objetos de Aprendizagem - Introdução e Fundamentos. Coleção Intera. Editora UFABC, 2014.

Butcher, N. Edited by: Kanwar, A. and Uvalic - Trumbic, S. (2011) "A Basic Guide to Open Educational Resources (OER)”, Commonwealth of Learning, Vancouver, CA.

Creative Commons (2018) "About the Licenses" - Function and design In: https://creativecommons.org/licenses/.

Krueger, C.W. "Software Reuse", ACM Comput. Surv., 24(2), 131-183, 1992.

Silveira, Ismar Frango . Rumo ao Reúso: Recursos Educacionais Abertos. In: Braga, J.. (Org.). Objetos de Aprendizagem. 1ed.: Editora da UFABC, 2014, v. 1, p. 127-148. 
VII Congresso Brasileiro de Informática na Educação (CBIE 2018)

Anais do XXIX Simpósio Brasileiro de Informática na Educação (SBIE 2018)

Santos, A.I. (2014) "Inovação na Educação Básica e Tecnologias Educacionais Aplicando os 4 R's dos Recursos Educacionais Abertos" - Coleção Agrinho - págs 249-254. - Sistema FAEP - Paraná, 2014.

Sommerville, I. "Software Engineering", 9th ed. Pearson Education. 2011

Tarouco, L.M.R. "Fatores que afetam o reuso de objetos de aprendizagem" CINTEDUFRGS Novas Tecnologias na Educação V. 9 N 1, julho, 2011.

UNESCO (2012) "Open Educational Resources" - Communication and Information Access to Knowledge - In: http://www.unesco.org/new/pt/brasilia/communicationand-information/access-to-knowledge/ict-in-education/open-educational-resources/

Wiley, D. (2014) "The Access Compromise and the 5th R" - Iterating Toward Openess - in https://opencontent.org/blog/archives/3221, 2014.

Wiley, David. Impediments to Learning Object Reuse and Openness as a Potential Solution"-RBIE, Vol. 17, n.3, 2009. 